\section{Grundig oppdatering om Alzheimers sykdom}

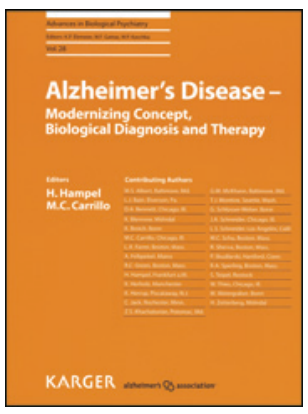

Harald Hampel, Maria C. Carrillo

Alzheimer's disease

Modernizing concept, biological diagnosis and therapy. 193 s, tab, ill. Basel: Karger, 2012.

Pris CHF 67

ISBN 978-3-8055-9802-6

Siden Alzheimers sykdom først ble beskrevet i 1906 har det skjedd en voldsom utvikling i kunnskapen om sykdommen. De siste tiårene har forskning på biologiske årsaker til sykdommen økt kraftig, noe som gjenspeiler seg i de nyeste diagnostiske kriteriene og utviklingen av nye, mulige behandlingsmetoder.

Alzheimer's disease inngår i serien Advances in Biological Psychiatry, om biologiske aspekter ved psykiatriske sykdommer. Gjennom ti kapitler oppdateres leseren grundig om genetikk, kliniske kriterier, biomarkører i spinalvæsken, MR og PET-scan, farmakologisk behandling og forskningsmetodikk ved biologisk, psykiatrisk forskning. Hvert kapittel er skrevet av eksperter og forskere innen feltet, og alt er redigert av to ledende eksperter. Kapitlene er bygd opp som oversiktsartikler, med innledende sammendrag og avsluttende referanseliste. Referanselistene er omfattende og oppdaterte, med mange referanser fra 2011.

Hvert kapittel står på egne bein og kan leses uavhengig av de andre. Språket er godt og flytende, og kapitlene er inndelt i underkapitler som strukturerer innholdet. Det er flere tabeller, men bare noen få figurer. Kapitlene er tilgjengelige elektronisk bak en betalingsmur. Målgruppen anser jeg å være klinikere og forskere med bakgrunnskunnskap om demens og Alzheimers sykdom, men også andre leger og medisinstudenter som ønsker en grundig oppdatering om sykdommen, vil finne boken interessant.

Problemet med skriftlig formidling av kunnskap i medisinen er at innholdet ofte er utdatert ved utgivelsestidspunkt. Dette er løst forbilledlig her ved at boken er bygd opp som enkeltstående oversiktsartikler, og hver artikkel er oppdatert hver for seg. På den andre siden er faren for gjentakelser en av ulempene ved en slik løsning, noe man heller ikke her har unngått. Likevel er mitt inntrykk at den redaksjonelle redigeringen av kapitlene har vært relativt stram, slik at dette ikke ødelegger for totalinntrykket. Jeg vil likevel anbefale leseren å lese boken i porsjoner eller som enkeltartikler, da det likevel ikke er naturlige overganger mellom kapitlene. Særlig kapitlene om diagnostiske kriterier, biomarkører i spinalvæske og MR og PET-scan, i tillegg til kapitlet om farmakologisk behandling, er interessante og lærerike.

Boken er satt med tekst i full sidebredde, og personlig synes jeg at det hadde vært lettere å lese teksten om den hadde vært satt opp $\mathrm{i}$ to kolonner.

Alzheimer's disease er en flott samling artikler som gjør leseren klokere, samtidig som artiklene vekker nysgjerrigheten til å lese mer. Boken vil ikke erstatte lærebøker, men vil være et nyttig supplement og en oppdatering for dem som allerede har kunnskap om sykdommen. Mange vil ha glede av å lese den.

\section{Sverre Bergh}

Alderspsykiatrisk forskningssenter

Sykehuset Innlandet

\section{Palliativ behandling i et tverrfaglig, globalt og samfunnsmedisinsk perspektiv}

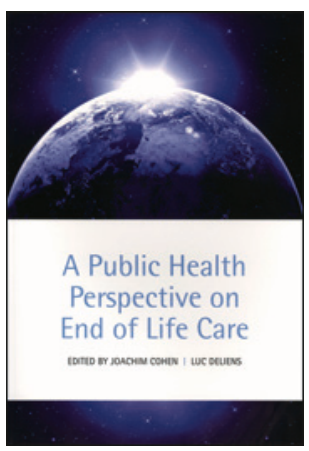

Joachim Cohen, Luc Deliens, red

A public health perspective on end of life care

255 s, tab, ill. Oxford: Oxford University Press, 2012. Pris GBP 35

ISBN 978-0-19-959940-0

Palliasjon har sitt utspring i hospicebevegelsen og har hovedsakelig hatt sitt søkelys på lindrende behandling av kreftsyke. Behandlingen har dreid seg om å hjelpe den døende og de pårørende gjennom den vanskelige avsluttende fasen av livet. Andelen eldre $\mathrm{i}$ befolkningen er økende, og stadig flere dør av kroniske lidelser, og flere vil kunne ha nytte av god lindrende behandling mot livets slutt. Med de demografiske utfordringene vi står overfor, både nasjonalt og globalt, tar forfatterne til orde for at det er nødvendig med et samfunnsmedisinsk perspektiv på palliasjon. Et imponerende lag av internasjonale forskere, administratorer og klinikere har her gått sammen om å beskrive utfordringene.

I den første delen beskriver forfatterne de demografiske utfordringene og fremveksten av palliativ behandling som et spesialområde. I den andre delen diskuterer de de sosiale og kulturelle aspektene rundt det å dø. Her fremhever de spesielt diskrepansen mellom ønsket dødssted (hjemmet) og der folk faktisk ender sine liv. Den tredje delen omhandler tilgjengelighet til palliativ medisin, og de diskuterer blant annet dilemmaene knyttet til avslutning av intensiv behandling. Deretter beskriver de aspekter knyttet til behandling i hjemmet, sykehjem og sykehus. En rekke kapitler er viet andre grupper enn kreftpasienter som har behov for lindrende behandling. I denne delen er bidragsyterne særlig opptatt av lik rett til behandling, uavhengig av bosted og sosial status. Det leder opp til en diskusjon om hvilken politikk som bør føres på området for å gi et faglig godt og likeverdig tilbud til befolkningen. Her vektlegger de betydningen av en tverrfaglig tilnærming med et tydelig brukerperspektiv.

Budskapet er klart. Utfordringene innenfor lindrende behandling er store og krever en bred mobilisering i befolkningen generelt og hos helseplanleggere spesielt. De sosiale, kulturelle og økonomiske forholdene må tas med når fremtidens lindrende behandling skal planlegges. Særlig trekker bidragsyterne frem utfordringene i primærhelsetjenesten og behovet for høyt spesialiserte palliative team som kan understøtte førstelinjen for å gi lindrende behandling av god kvalitet i hjemmet eller på en lokal institusjon. Samhandling mellom tjenestenivåene står sentralt.

Boken kan være nyttig for planleggere av helsetjenesten på alle nivåer i helsetjenesten. Men også klinikere med palliasjon som sitt spesiale, vil kunne ha nytte av å sette sitt fagområde inn i en samfunnsmedisinsk sammenheng.

Arne Johannesen

Spesialist i samfunnsmedisin og psykiatri

Psykiatrisk klinikk

Sykehuset Telemark 